\title{
Molecular Pathology Testing for Non-small Cell Lung Cancer: An Observational Study of Elements Currently Present in Request Forms and Result Reports and The Opinion of Different Stakeholders
}

Kelly Dufraing

University of Leuven, Department of Public Health and Primary Care, Biomedical Quality Assurance Research Unit

\section{Kaat Van Casteren}

University of Leuven, Department of Public Health and Primary Care, Biomedical Quality Assurance Research Unit

Joke Breyne

Department of Molecular Diagnostics, AZ Delta Roeselare Menen

Nicky D'Haene

Department of Pathology, Erasme University Hospital, Brussels

Claude Van Campenhout

Department of Pathology, Erasme University Hospital, Brussels

\section{Sara Vander Borght}

Pathology Department, University Hospitals Leuven, Leuven

\section{Karen Zwaenepoel}

Laboratory of Pathological Anatomy, Antwerp University Hospital, Edegem

\section{Etienne Rouleau}

Medical Biology and Pathology, Gustave Roussy, Paris

\section{Ed Schuuring}

Department of Pathology, University of Groningen, University Medical Center Groningen (UMCG)

Jan von der Thüsen

Department of pathology, VU University Medical Center (VUMC) Amsterdam, Amsterdam

Elisabeth Dequeker ( $\square$ els.dequeker@kuleuven.be)

University of Leuven, Department of Public Health and Primary Care, Biomedical Quality Assurance Research Unit

\section{Research Article}

Keywords: Non-small-cell lung cancer, molecular pathology, test requesting, test report, pre-analytical phase, post-analytical phase

Posted Date: April 9th, 2021

DOI: https://doi.org/10.21203/rs.3.rs-149142/v1

License: () (i) This work is licensed under a Creative Commons Attribution 4.0 International License. Read Full License 


\section{Abstract}

\section{Background}

For patients with non-small cell lung cancer (NSCLC), targeted therapies are becoming part of the standard treatment. It is of question which information the clinicians provide on test requests and how the laboratories adapt test conclusions to this knowledge and regulations.

\section{Methods}

This study consisted of two components; 1) checking the presence of pre-defined elements (administrative and key for therapy-choice) on completed requests and corresponding reports in Belgian laboratories, both for tissue- and liquid biopsy (LB)-testing and b) opinion analysis from Belgian pathologists/molecular biologists and clinicians during national pathology/oncology meetings.

\section{Results}

Data from 4 out of 6 Belgian laboratories with ISO-accreditation for LB-testing were analyzed, of which $75 \%$ were university hospitals. On the scored requests $(\mathrm{N}=4), 12$ out of 19 ISO-required elements were present for tissue and 11 for LB-testing. Especially relevant patient history, such as line of therapy (for LB), tumor histology and the reason for testing were lacking. Similarly, 11 and 9 out of 18 elements were present in the reports $(\mathrm{N}=4)$ for tissue and $L B$, respectively.

Elements that pathologists/molecular biologists $(\mathrm{N}=18)$ were missing on the request were the initial activating mutation, previous therapies, a clinical question and testing-related information. For reporting, an item considered important by both groups is the clinical interpretation of the test result. In addition, clinicians $(\mathrm{N}=28)$ indicated that they also wish to read the percentage of neoplastic cells.

\section{Conclusions}

Communication flows between the laboratory and the clinician, together with possible pitfalls were identified. Based on the study results, templates for complete requesting and reporting were proposed.

\section{Background}

For patients with metastatic non-small cell lung cancer (NSCLC), targeted therapies have taken over the position as the standard treatment for tumors with susceptible genomic alterations. For example, EGFR tyrosine kinase inhibitors (EGFR-TKIs) are now the firstline treatment for patients with NSCLC with a confirmed actionable EGFR variant. These shifts in treatment options require a concomitant expansion of knowledge for clinicians. It is of interest which information regarding the lines of treatment the clinicians provide on their test request forms and how the laboratories correspondingly adapt their reports, including the test conclusion, to this information. Effective communication between the molecular pathology laboratory and the test ordering clinician is thus indispensable for correct test interpretation, and by consequence perhaps also for administering the correct therapy (1).

The laboratory can only perform the correct test and correctly interpret the result when the right question is provided together with the necessary background information. Therefore, laboratories could create a request form template that stimulates clinicians to submit the correct and complete information. Although this request form template might contain the minimally required elements to be filled in, it is not known whether the clinician truly completes all fields and whether they are appropriately interpreted. Studies in the field of hereditary cancer have indeed indicated problems with form completeness $(2,3)$. In addition to the completeness of test requests, adequate reporting of the test result by the laboratory is in turn important for efficient communication to the clinician. Although guidelines and checklists on the elements of the test report have been published, these are rather general and do not always fully apply to NSCLC nor are they applicable to multiple testing methods (4). Furthermore, it remains unclear whether clinicians find each element on the report useful and whether they correctly translate the report to the best treatment decision (5). For example, a study by Heller et al. indicated that $39 \%(\mathrm{~N}=91)$ of the clinicians did not fully understand the pathology testing results in vulvovaginal disease (6). Another study by Lubin et al. in the field of hereditary diseases confirms these opinions from clinicians (7).

NSCLC is a complex disease which is subject to significant and progressive change in the tumor genome. Despite initial responses, most patients show disease progression within one to two years after treatment with first-, second- and even third- generation EGFR-TKIs. The most common mechanism of resistance is the development of an additional EGFR-T790M variant in exon 20. Phase II and III trials with osimertinib (Tagrisso@ , AstraZeneca), a third-generation EGFR-TKI, demonstrated an objective response rate (ORR) of $60-70 \%$ and 
median progression-free survival (mPFS) of 10-11 months in EGFR-T790M-positive tumors. Based on the results of the phase III FLAURA trial, the use of osimertinib for the first-line treatment of patients with inoperable or recurrent EGFR mutation-positive NSCLC was approved in 2018 (8). It is important that clinicians are aware of such changes in sequencing of preferential treatment, since this might impact the process of requesting and/or reporting flow of biomarker testing.

Several flow charts of biomarker testing for NSCLC are used in practice. For example, a laboratory can opt for simultaneous testing of the different markers (EGFR, ALK, ROS1 and PD-L1) or for sequential testing. For the latter, the test results for the various biomarkers become available at different times. This might also impact reporting of results; thus, do laboratories have one integrated report with one conclusion regarding therapy for all biomarkers, or a separate report for each marker? If the latter is the case, it is debatable whether clinicians are aware that they need to wait for all information before starting the treatment.

Tissue biopsies are currently standard practice in the management of cancer patients. However, sometimes retrieving these tissue samples carries considerable risk to the patient. Therefore, the use of liquid biopsies (blood, urine, saliva, ...) as a complement to tissue biopsies is of great interest, especially for repeated EGFR-T790M testing $(9,10)$. Given the different contexts for plasma testing (initial diagnosis versus progression), clear information on the request form and in the report are of utmost importance.

Several providers of external quality assessment (EQA) are already assessing reports as part of the proficiency testing program, based on the guideline by van Krieken et al. (11). Results from these programs and a study in which routine reports were analyzed, already show the high variability between report content and layout (12). To gain insight in the causes of this variability and how it can be improved this study was initiated as part of a national quality improvement project. There was a twofold aim: 1) to guide Belgian clinicians in providing the laboratory with sufficient information for biomarker testing and result interpretation and 2) to guide Belgian laboratories in reporting the results of biomarker analysis in a clinician-friendly way. Both aims apply to tissue testing and liquid biopsy testing for NSCLC.

\section{Methods}

This study was subdivided in two major components; a) listing the 'as is' situation in selected Belgian laboratories, and b) analysis of opinions regarding requesting and reporting from both Belgian pathologists/molecular biologists and clinicians using a similar questionnaire.

\section{The total testing process in the visited laboratories}

Four Belgian molecular pathology laboratories were included in the study based on their ISO 15189:2012 accreditation status for NSCLC testing on both tissue and plasma and their willingness to participate. Communication flows (from requesting to result reporting) were determined based on interviews with delegates from the molecular pathology laboratory.

\section{Defining what is currently included in requests and reports vs what should be according to guidelines}

During a laboratory visit, the presence of pre-defined elements was studied on request form templates $(\mathrm{N}=4)$ and reports $(\mathrm{N}=4)$ using a checklist (see Additional file 1). Three documents were identified as applicable to both requesting molecular pathology tests and reporting test results in Belgium: a) a Royal Decree $(13,14)$, b) the code of practice for pathological anatomy (15) and c) ISO 15189:2012 (16). In addition, European and international guidelines applicable to requesting and/or reporting were identified: a) a checklist developed by the College of American Pathologists (17) and b) a French national guideline (14). These European and international guidelines are not legally applicable for Belgian laboratories, but since they have a stronger focus on non-small cell lung cancer they can be of educational value.

For reporting only, data were also added from 2 EQA schemes for tissue testing (the Lung EQA scheme from the European Society of Pathology (ESP) of 2019 and the French national Gen\&Tiss scheme of 2018-2019). In the molecular subscheme of the ESP Lung EQA scheme of 2019, laboratories submitted 1 molecular pathology report based on mock clinical information for a pre-selected case in which the EGFR c.2573T > G; p. (Leu858Arg) and c.2369C > T; p.(Thr790Met) variants were present, as described elsewhere (18). Similarly, the participants to the Gen\&Tiss scheme of 2018-2019 submitted, in addition to their genotyping results, 1 molecular pathology report for a sample which harbored an EGFR exon 19 deletion (19).

\section{Relation between clinical interpretations and request form}

Page $3 / 22$ 
The participating laboratories were asked to select nine reports and their corresponding request forms for tissue and eight for plasma testing based on pre-defined selection criteria (see Table 4). It was checked on all reports whether the clinical question on the request form was answered and whether this was done in a general or patient-specific way. General is hereby defined as 'the effect of the presence/absence of a variant on therapy response, as observed during previous clinical trials' and patient-specific by 'an interpretation that only applies to the specific patient'. 
Table 4

- relationship between clinical question on the request form and the test result interpretation on the test report in Belgium

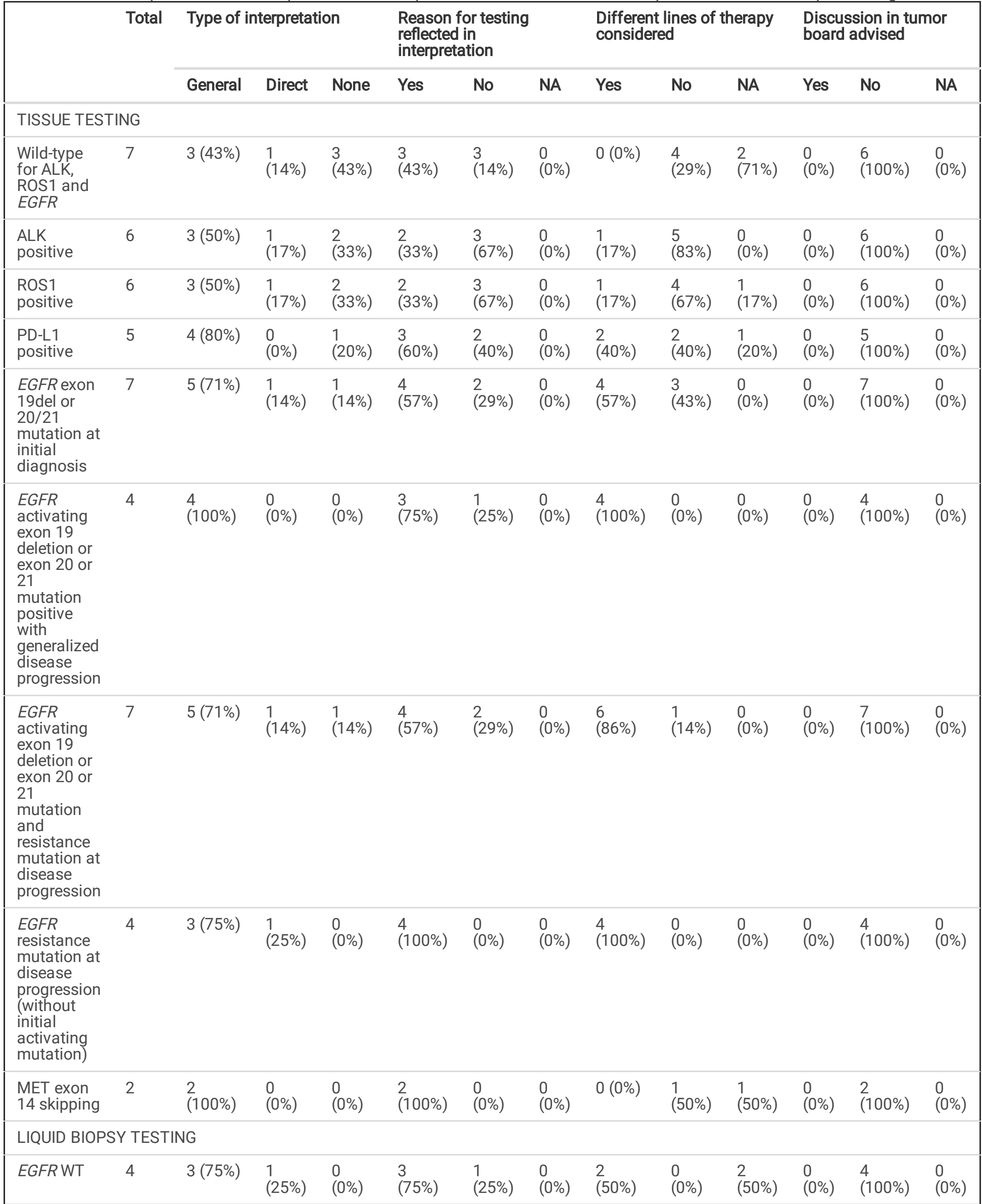

Page 5/22 


\begin{tabular}{|c|c|c|c|c|c|c|c|c|c|c|c|c|c|}
\hline & \multirow[t]{2}{*}{ Total } & \multicolumn{3}{|c|}{ Type of interpretation } & \multicolumn{3}{|c|}{$\begin{array}{l}\text { Reason for testing } \\
\text { reflected in } \\
\text { interpretation }\end{array}$} & \multicolumn{3}{|c|}{$\begin{array}{l}\text { Different lines of therapy } \\
\text { considered }\end{array}$} & \multicolumn{3}{|c|}{$\begin{array}{l}\text { Discussion in tumor } \\
\text { board advised }\end{array}$} \\
\hline & & General & Direct & None & Yes & No & NA & Yes & No & NA & Yes & No & NA \\
\hline $\begin{array}{l}\text { EGFR exon } \\
19 \text { del or } \\
20 / 21 \\
\text { mutation at } \\
\text { initial } \\
\text { diagnosis }\end{array}$ & 3 & $1(33 \%)$ & $\begin{array}{l}2 \\
(67 \%)\end{array}$ & $\begin{array}{l}0 \\
(0 \%)\end{array}$ & $\begin{array}{l}1 \\
(33 \%)\end{array}$ & $\begin{array}{l}2 \\
(67 \%)\end{array}$ & $\begin{array}{l}0 \\
(0 \%)\end{array}$ & $\begin{array}{l}3 \\
(100 \%)\end{array}$ & $\begin{array}{l}0 \\
(0 \%)\end{array}$ & $\begin{array}{l}0 \\
(0 \%)\end{array}$ & $\begin{array}{l}0 \\
(0 \%)\end{array}$ & $\begin{array}{l}3 \\
(100 \%)\end{array}$ & $\begin{array}{l}0 \\
(0 \%)\end{array}$ \\
\hline $\begin{array}{l}\text { EGFR exon } \\
19 \text { deletion } \\
\text { or exon } 20 \\
\text { or } 21 \\
\text { mutation } \\
\text { and } \\
\text { resistance } \\
\text { mutation at } \\
\text { disease } \\
\text { progression }\end{array}$ & 4 & $2(50 \%)$ & $\begin{array}{l}2 \\
(50 \%)\end{array}$ & $\begin{array}{l}0 \\
(0 \%)\end{array}$ & $\begin{array}{l}3 \\
(75 \%)\end{array}$ & $\begin{array}{l}1 \\
(25 \%)\end{array}$ & $\begin{array}{l}0 \\
(0 \%)\end{array}$ & $\begin{array}{l}4 \\
(100 \%)\end{array}$ & $\begin{array}{l}0 \\
(0 \%)\end{array}$ & $\begin{array}{l}0 \\
(0 \%)\end{array}$ & $\begin{array}{l}0 \\
(0 \%)\end{array}$ & $\begin{array}{l}4 \\
(100 \%)\end{array}$ & $\begin{array}{l}0 \\
(0 \%)\end{array}$ \\
\hline $\begin{array}{l}\text { EGFR } \\
\text { resistance } \\
\text { mutation at } \\
\text { disease } \\
\text { progression } \\
\text { (without } \\
\text { initial } \\
\text { mutation) }\end{array}$ & 2 & $1(50 \%)$ & $\begin{array}{l}1 \\
(50 \%)\end{array}$ & $\begin{array}{l}0 \\
(0 \%)\end{array}$ & $\begin{array}{l}2 \\
(100 \%)\end{array}$ & $\begin{array}{l}0 \\
(0 \%)\end{array}$ & $\begin{array}{l}0 \\
(0 \%)\end{array}$ & 2 & $\begin{array}{l}0 \\
(0 \%)\end{array}$ & $\begin{array}{l}0 \\
(0 \%)\end{array}$ & $\begin{array}{l}0 \\
(0 \%)\end{array}$ & 2 & $\begin{array}{l}0 \\
(0 \%)\end{array}$ \\
\hline $\begin{array}{l}\text { EGFR exon } \\
19 \text { deletion } \\
\text { or exon } 20 \\
\text { or } 21 \\
\text { mutation } \\
\text { positive } \\
\text { result after } \\
\text { disease } \\
\text { progression }\end{array}$ & 3 & $2(67$ & $\begin{array}{l}1 \\
(67 \%)\end{array}$ & $\begin{array}{l}0 \\
(0 \%)\end{array}$ & $\begin{array}{l}3 \\
(100 \%)\end{array}$ & $\begin{array}{l}0 \\
(0 \%)\end{array}$ & $\begin{array}{l}0 \\
(0 \%)\end{array}$ & $\begin{array}{l}3 \\
(100 \%)\end{array}$ & $\begin{array}{l}0 \\
(0 \%)\end{array}$ & $\begin{array}{l}0 \\
(0 \%)\end{array}$ & $\begin{array}{l}0 \\
(0 \%)\end{array}$ & $\begin{array}{l}3 \\
(100 \%)\end{array}$ & $\begin{array}{l}0 \\
(0 \%)\end{array}$ \\
\hline $\begin{array}{l}\text { Borderline } \\
\text { T790M }\end{array}$ & 1 & $1(100$ & $\begin{array}{l}0 \\
(0 \%)\end{array}$ & $\begin{array}{l}0 \\
(0 \%)\end{array}$ & $\begin{array}{l}1 \\
(100 \%)\end{array}$ & $\begin{array}{l}0 \\
(0 \%)\end{array}$ & $\begin{array}{l}0 \\
(0 \%)\end{array}$ & $\begin{array}{l}1 \\
(100 \%)\end{array}$ & $\begin{array}{l}0 \\
(0 \%)\end{array}$ & $\begin{array}{l}0 \\
(0 \%)\end{array}$ & $\begin{array}{l}0 \\
(0 \%)\end{array}$ & $\begin{array}{l}1 \\
(100 \%)\end{array}$ & $\begin{array}{l}0 \\
(0 \%)\end{array}$ \\
\hline
\end{tabular}

\section{Content of request forms and reports - opinions from providers and receivers}

Two systems were used to study the opinions from the laboratory side (pathologists and molecular biologists) and of the clinician: reallife voting during meetings/symposia and an online questionnaire. The real-life voting rounds were held as part of scientific symposia regarding NSCLC. Questions were presented during different sessions of national expert meetings between October 2018 and March 2019. The attendees had to answer the presented questions via an online voting system (PollEverywhere.com, Poll Everywhere Inc., San Francisco, Unites States). During each session, a set of basic questions were asked, which were extended with additional questions according to the target audience. An overview of the questions asked is shown in Additional file 2. In addition to the real-life voting sessions, a link to an online questionnaire (FormDesk software version 4.0.14, Innovero Software Solutions B.V., Wassenaar, the Netherlands) was spread via the Belgian AstraZeneca Newsletter of September 2019 (see Additional file 3).

\section{Results}

\section{The total testing process in the visited laboratories}

In the visited hospitals, molecular pathology laboratories were a structural part of the 'pathology department' ( $N=2)$ or part of a unit separate from the 'pathology department' $(\mathrm{N}=2)$, whether or not as part of the center for human genetics (Fig. 1). In both structures, the entire testing process (requesting tests, performing tests and reporting test results) is different and there are other pitfalls. Table 1 shows the testing characteristics of the visited laboratories. In the majority, reflex testing and parallel testing co-existed, by choice of the 
laboratory or clinician. All laboratories tested for the EFGR gene in-house, but other genes could be outsourced. Most laboratories had a turnaround time between 8 and 14 calendar days.

Table 1

- characteristics of the study population

\begin{tabular}{|c|c|c|}
\hline Characteristic & $\mathbf{N}$ & $\%(N=4)$ \\
\hline \multicolumn{3}{|l|}{ Type of testing } \\
\hline Reflex testing & 2 & $50 \%$ \\
\hline Parallel testing & 0 & $0 \%$ \\
\hline Combination & 1 & $25 \%$ \\
\hline Clinician can choose & 2 & $50 \%$ \\
\hline \multicolumn{3}{|l|}{ Genes/proteins tested for NSCLC } \\
\hline$E G F R$ & 4 & $100 \%$ \\
\hline$A L K$ & 4 & $100 \%$ \\
\hline ROS1 & 4 & $100 \%$ \\
\hline$P D-L 1$ & 4 & $100 \%$ \\
\hline KRAS & 4 & $100 \%$ \\
\hline$B R A F$ & 4 & $100 \%$ \\
\hline$M E T$ & 4 & $100 \%$ \\
\hline \multicolumn{3}{|l|}{ Average turnaround time (in calendar days) } \\
\hline $1-7$ & 0 & $0 \%$ \\
\hline $8-14$ & 3 & $75 \%$ \\
\hline $15-21$ & 1 & $25 \%$ \\
\hline$>21$ & 0 & $0 \%$ \\
\hline Tissue testing: in routine $\&$ accredited & 4 & $100 \%$ \\
\hline Liquid biopsy testing: in routine $\&$ accredited & 4 & $100 \%$ \\
\hline \multicolumn{3}{|l|}{ Input data from request form to the LIS } \\
\hline Manually & 3 & $75 \%$ \\
\hline Automatically (via barcoding) & 1 & $25 \%$ \\
\hline
\end{tabular}

\section{What is currently included in requests and reports vs what should be according to guidelines?}

The presence of pre-defined elements was checked on four request forms and four reports for both tissue- and liquid biopsy testing during the laboratory visits (Table 2A and 2B).

Related to requesting, 19 of the scored elements are currently mandatory according to laws/standards applicable in Belgium $(13,20)$. Of these required elements, only twelve for tissue and eleven for liquid biopsies were included by all four visited laboratories (marked in green in Table 2A). Especially the availability of the indications for testing (for tissue), the address of the test prescriber, relevant patient history (for plasma), the tumor histology and the reason for testing are points of attention in the online laboratory guide (marked in red in Table 2A). 
Table 2

A - presence of scored elements in request forms from visited Belgian laboratories versus elements required by guidelines/standards

\begin{tabular}{|c|c|}
\hline Element & $\begin{array}{l}\text { Present for tissue } \\
\text { testing }\end{array}$ \\
\hline
\end{tabular}

$(13,15,16,20) \quad(36)$

$\begin{array}{lll}\text { REQUEST FORMS } \quad \mathrm{N}=4 & \mathrm{~N}=4\end{array}$

Accessibility and design

$\begin{array}{ll}\text { Molecular pathology } & 4(100 \%)\end{array} \quad 1(25 \%)$

dedicated form

Lung cancer dedicated form $0(0 \%) \quad 0(0 \%)$

Request available online $\quad 4(100 \%) \quad 4(100 \%)$

Testing technique specified $\quad 4(100 \%) \quad 3(75 \%)$

Online: summary of test $\quad 2(50 \%) \quad 1(25 \%)$

methodology

$\begin{array}{lll}\text { Online: indications for } & 2(50 \%) & 3(75 \%)\end{array}$

testing

Online: recipient

$4(100 \%)$

Online: transport medium

$4(100 \%)$

$4(100 \%)$

)

Online: max delay for

transport

NA

NA

)

Online: storage

$4(100 \%)$

$4(100 \%)$

)

Digital storage completed

forms

$3(75 \%) \quad 3(75 \%)$

Administrative elements

Prescriber: name

$4(100 \%)$

$4(100 \%)$

)

1

Prescriber: address

$2(50 \%)$

$2(50 \%)$

)

$4(100 \%)$

)

I

equivalent

Prescriber: department

$1(25 \%)$

$1(25 \%)$

1

Reimbursement info

$1(25 \%)$

$2(50 \%)$

General lab address

$4(100 \%)$

$4(100 \%)$

)

Contact person in lab

$1(25 \%)$

$2(50 \%)$

Patient characteristics

\begin{tabular}{|c|c|c|c|c|}
\hline Patient: name & $4(100 \%)$ & $4(100 \%)$ & 1 & ) \\
\hline Patient: DOB & $4(100 \%)$ & $4(100 \%)$ & 1 & ) \\
\hline Patient: gender & $4(100 \%)$ & $4(100 \%)$ & 1 & ) \\
\hline Patient: address & $4(100 \%)$ & $4(100 \%)$ & ) & ) \\
\hline Patient: internal hospital ref & $4(100 \%$ & $4(100 \%)$ & ) & ) \\
\hline Relevant patient history & $4(100 \%)$ & $2(50 \%)$ & 1 & 1 \\
\hline Histology of tumor & $2(50 \%)$ & $2(50 \%)$ & 1 & ) \\
\hline
\end{tabular}

Numbers in green: elements that were included by $100 \%$ of the laboratories which are required by national or international guidelines. Numbers in red: elements that were included by $\leq 50 \%$ of the laboratories which are required by national or international guidelines. Numbers in bold: elements for which a large difference ( $\geq 30 \%)$ exists between tissue and liquid biopsy testing. 


\begin{tabular}{|c|c|c|c|c|}
\hline Element & $\begin{array}{l}\text { Present for tissue } \\
\text { testing }\end{array}$ & $\begin{array}{l}\text { Present for liquid } \\
\text { biopsy testing }\end{array}$ & $\begin{array}{l}\text { Required by Belgian } \\
\text { standards } \\
(13,15,16,20)\end{array}$ & $\begin{array}{l}\text { Required by international } \\
\text { guidelines } \\
\text { (36) }\end{array}$ \\
\hline Primary diagnosis & $1(25 \%)$ & $3(75 \%)$ & & ) \\
\hline Previous tests performed & $3(75 \%)$ & $3(75 \%)$ & & ) \\
\hline Original activating mutation & $1(25 \%)$ & $2(50 \%)$ & & ) \\
\hline Previous therapies (type) & $4(0 \%)$ & $1(25 \%)$ & & 1 \\
\hline Previous therapies (time) & $0(0 \%)$ & $0(0 \%)$ & & \\
\hline Progression/not & $3(75 \%)$ & $3(75 \%)$ & & ) \\
\hline Progression type & $1(25 \%)$ & $2(50 \%)$ & & \\
\hline Progression time & $0(0 \%)$ & $0(0 \%)$ & & \\
\hline Location primary tumor & $3(75 \%)$ & $3(75 \%)$ & & \\
\hline Tumor stage & $3(75 \%)$ & $3(75 \%)$ & & ) \\
\hline Reason for testing & $0(0 \%)$ & $1(25 \%)$ & I & ) \\
\hline \multicolumn{5}{|l|}{ Sample characteristics } \\
\hline Sample type & $4(100 \%)$ & $4(100 \%)$ & I & ) \\
\hline $\begin{array}{l}\text { Number of } \\
\text { slides/blocks/tubes }\end{array}$ & $3(75 \%)$ & $4(100 \%)$ & & \\
\hline Fixative & $4(100 \%)$ & NA & & \\
\hline Fixation time & $4(100 \%)$ & NA & & \\
\hline $\begin{array}{l}\text { Specification of total } \\
\text { blood/plasma }\end{array}$ & NA & $0(0 \%)$ & & \\
\hline Type of collection tube & NA & $3(75 \%)$ & & \\
\hline Date of sample collection & NA & $3(75 \%)$ & 1 & \\
\hline Time of sample collection & NA & $3(75 \%)$ & ) & \\
\hline
\end{tabular}


Table 2

B - presence of scored elements in analyzed reports versus elements required by guidelines/standards

$\begin{array}{llll}\text { Element } & \text { Present for tissue testing } & \begin{array}{l}\text { Present for liquid } \\ \text { biopsy testing }\end{array} & \begin{array}{l}\text { Required by Belgian } \\ \text { standards }(13,15,16,20)\end{array} \\ & & \begin{array}{l}\text { Required by } \\ \text { international } \\ \text { guidelines }\end{array}\end{array}$

$(14,17,36,37)$

$\begin{array}{lllll}\text { REPORTS } & \begin{array}{l}\text { Visited } \\ \text { labs }\end{array} & \begin{array}{l}\text { ESP } \\ \text { labs }\end{array} & \begin{array}{l}\text { G\&T } \\ \text { labs }\end{array} & \text { Visited labs } \\ & \mathrm{N}=4 & \mathrm{~N}=86 & \mathrm{~N}=47 & \mathrm{~N}=4\end{array}$

Administrative elements

\begin{tabular}{|c|c|c|c|c|c|c|}
\hline $\begin{array}{l}\text { Requesting } \\
\text { physician: name }\end{array}$ & $\begin{array}{l}4 \\
(100 \%)\end{array}$ & $\begin{array}{l}77 \\
(90 \%)\end{array}$ & $\begin{array}{l}47 \\
(100 \%)\end{array}$ & $4(100 \%)$ & 1 & ) \\
\hline $\begin{array}{l}\text { Requesting } \\
\text { physician: address }\end{array}$ & $\begin{array}{l}4 \\
(100 \%)\end{array}$ & $\begin{array}{l}67 \\
(78 \%)\end{array}$ & $\begin{array}{l}42 \\
(89 \%)\end{array}$ & $4(100 \%)$ & 1 & 1 \\
\hline Patient: name & $\begin{array}{l}4 \\
(100 \%)\end{array}$ & $\begin{array}{l}79 \\
(92 \%)\end{array}$ & $\begin{array}{l}47 \\
(100 \%)\end{array}$ & $4(100 \%)$ & l & ) \\
\hline Patient: address & $\begin{array}{l}2 \\
(50 \%)\end{array}$ & $\begin{array}{l}10 \\
(12 \%)\end{array}$ & $1(2 \%)$ & $3(75 \%)$ & & \\
\hline $\begin{array}{l}\text { Patient: date of } \\
\text { birth }\end{array}$ & $\begin{array}{l}4 \\
(100 \%)\end{array}$ & $\begin{array}{l}78 \\
(91 \%)\end{array}$ & $\begin{array}{l}46 \\
(98 \%)\end{array}$ & $4(100 \%)$ & 1 & ) \\
\hline Patient: gender & $\begin{array}{l}4 \\
(100 \%)\end{array}$ & $\begin{array}{l}71 \\
(83 \%)\end{array}$ & $\begin{array}{l}40 \\
(85 \%)\end{array}$ & $4(100 \%)$ & & ) \\
\hline $\begin{array}{l}\text { Name report } \\
\text { authorizer }\end{array}$ & $\begin{array}{l}4 \\
(100 \%)\end{array}$ & $\begin{array}{l}76 \\
(88 \%)\end{array}$ & $\begin{array}{l}40 \\
(85 \%)\end{array}$ & $4(100 \%)$ & 1 & ) \\
\hline $\begin{array}{l}\text { Signature report } \\
\text { authorizer }\end{array}$ & $\begin{array}{l}3 \\
(75 \%)\end{array}$ & $\begin{array}{l}63 \\
(73 \%)\end{array}$ & $\begin{array}{l}41 \\
(87 \%)\end{array}$ & $3(75 \%)$ & & 1 \\
\hline Request date & $\begin{array}{l}2 \\
(50 \%)\end{array}$ & $\begin{array}{l}48 \\
(56 \%)\end{array}$ & $\begin{array}{l}32 \\
(68 \%)\end{array}$ & $3(75 \%)$ & & ) \\
\hline $\begin{array}{l}\text { Sample collection } \\
\text { date }\end{array}$ & $\begin{array}{l}4 \\
(100 \%)\end{array}$ & $\begin{array}{l}61 \\
(71 \%)\end{array}$ & $\begin{array}{l}46 \\
(98 \%)\end{array}$ & $3(75 \%)$ & 1 & ) \\
\hline Sample arrival date & $\begin{array}{l}3 \\
(75 \%)\end{array}$ & $\begin{array}{l}56 \\
(65 \%)\end{array}$ & $\begin{array}{l}45 \\
(96 \%)\end{array}$ & $3(75 \%)$ & 1 & 1 \\
\hline $\begin{array}{l}\text { Report validation } \\
\text { date }\end{array}$ & $\begin{array}{l}4 \\
(100 \%)\end{array}$ & $\begin{array}{l}74 \\
(86 \%)\end{array}$ & $\begin{array}{l}42 \\
(89 \%)\end{array}$ & $3(75 \%)$ & 1 & 1 \\
\hline $\begin{array}{l}\text { Page } \mathrm{nr} / \text { total } \\
\text { pages }\end{array}$ & $\begin{array}{l}2 \\
(50 \%)\end{array}$ & $\begin{array}{l}55 \\
(64 \%)\end{array}$ & $\begin{array}{l}43 \\
(91 \%)\end{array}$ & $2(50 \%)$ & 1 & ) \\
\hline $\begin{array}{l}\text { Concise titles of } \\
\text { the analysis }\end{array}$ & $\begin{array}{l}2 \\
(50 \%)\end{array}$ & $\begin{array}{l}55 \\
(64 \%)\end{array}$ & $\begin{array}{l}45 \\
(96 \%)\end{array}$ & $2(50 \%)$ & & 1 \\
\hline
\end{tabular}

Clinical information

$\begin{array}{lllllll}\text { Patient history } & \begin{array}{l}4 \\ (100 \%)\end{array} & \begin{array}{l}76 \\ (88 \%)\end{array} & \begin{array}{l}44 \\ (94 \%)\end{array} & 4(100 \%) & \text { ) } \\ \begin{array}{l}\text { Planned line of } \\ \text { therapy }\end{array} & \mathbf{0 ( 0 \% )} & 3(3 \%) & \begin{array}{l}6 \\ (13 \%)\end{array} & 2(50 \%) & \text { ) } \\ \text { Reason for testing } & \begin{array}{l}\text { 2 } \\ (50 \%)\end{array} & \begin{array}{l}68 \\ (79 \%)\end{array} & \begin{array}{l}21 \\ (45 \%)\end{array} & 3(75 \%) & \text { ) }\end{array}$

Sample characteristics

Numbers in green: elements that were included by $100 \%$ of the laboratories which are required by national or international guidelines. Numbers in red: elements that were included by $\leq 50 \%$ of the laboratories which are required by national or international guidelines. Numbers in bold: elements for which a large difference ( $\geq 30 \%)$ exists between tissue and liquid biopsy testing. ESP: European Society of Pathology, G\&T: Gen\&Tiss (French national external quality assessment scheme) 


\begin{tabular}{|c|c|c|c|c|c|c|}
\hline \multirow{2}{*}{$\begin{array}{l}\text { Element } \\
\text { Sample type }\end{array}$} & \multicolumn{3}{|c|}{ Present for tissue testing } & \multirow{2}{*}{$\begin{array}{l}\text { Present for liquid } \\
\text { biopsy testing }\end{array}$} & \multirow{2}{*}{$\begin{array}{l}\text { Required by Belgian } \\
\text { standards }(13,15,16,20)\end{array}$} & \multirow{2}{*}{$\begin{array}{l}\begin{array}{l}\text { Required by } \\
\text { international } \\
\text { guidelines }\end{array} \\
(14,17,36,37) \\
\end{array}$} \\
\hline & $\begin{array}{l}4 \\
(100 \%)\end{array}$ & $\begin{array}{l}80 \\
(93 \%)\end{array}$ & $\begin{array}{l}38 \\
(81 \%)\end{array}$ & & & \\
\hline Sample number & $\begin{array}{l}3 \\
(75 \%)\end{array}$ & $\begin{array}{l}83 \\
(97 \%)\end{array}$ & $\begin{array}{l}46 \\
(98 \%)\end{array}$ & $3(75 \%)$ & & ) \\
\hline$\%$ neoplastic cells & $\begin{array}{l}4 \\
(100 \%)\end{array}$ & $\begin{array}{l}77 \\
(90 \%)\end{array}$ & $\begin{array}{l}46 \\
(98 \%)\end{array}$ & NA & & ) \\
\hline ml blood analyzed & NA & NA & NA & $1(25 \%)$ & & \\
\hline \multicolumn{7}{|l|}{ Method description } \\
\hline IVD/LDT & $\begin{array}{l}2 \\
(50 \%)\end{array}$ & $\begin{array}{l}16 \\
(19 \%)\end{array}$ & $\begin{array}{l}6 \\
(13 \%)\end{array}$ & $1(25 \%)$ & & 1 \\
\hline $\begin{array}{l}\text { DNA extraction } \\
\text { method }\end{array}$ & $\begin{array}{l}1 \\
(25 \%)\end{array}$ & $\begin{array}{l}35 \\
(41 \%)\end{array}$ & $\begin{array}{l}26 \\
(55 \%)\end{array}$ & $3(75 \%)$ & ) & \\
\hline $\begin{array}{l}\text { Variant analysis } \\
\text { method }\end{array}$ & $\begin{array}{l}4 \\
(100 \%)\end{array}$ & $\begin{array}{l}80 \\
(93 \%)\end{array}$ & $\begin{array}{l}47 \\
(100 \%)\end{array}$ & $4(100 \%)$ & ) & ) \\
\hline $\begin{array}{l}\text { Pre-analytical } \\
\text { conditions }\end{array}$ & $\begin{array}{l}2 \\
(50 \%)\end{array}$ & $8(9 \%)$ & $2(4 \%)$ & $0(0 \%)$ & 1 & ) \\
\hline $\begin{array}{l}\text { Sensitivity testing } \\
\text { method }\end{array}$ & $\begin{array}{l}4 \\
(100 \%)\end{array}$ & $\begin{array}{l}69 \\
(80 \%)\end{array}$ & $\begin{array}{l}44 \\
(94 \%)\end{array}$ & $4(100 \%)$ & & ) \\
\hline $\begin{array}{l}\text { Overview } \\
\text { alterations tested }\end{array}$ & $\begin{array}{l}2 \\
(50 \%)\end{array}$ & $\begin{array}{l}79 \\
(92 \%)\end{array}$ & $\begin{array}{l}43 \\
(91 \%)\end{array}$ & $3(75 \%)$ & ) & ) \\
\hline $\begin{array}{l}\text { Reference } \\
\text { sequence }\end{array}$ & $\begin{array}{l}2 \\
(50 \%)\end{array}$ & $\begin{array}{l}44 \\
(51 \%)\end{array}$ & $\begin{array}{l}7 \\
(15 \%)\end{array}$ & $1(25 \%)$ & ) & ) \\
\hline \multicolumn{7}{|l|}{ Results } \\
\hline Mutation status & $\begin{array}{l}4 \\
(100 \%)\end{array}$ & $\begin{array}{l}86 \\
(100 \%)\end{array}$ & $\begin{array}{l}47 \\
(100 \%)\end{array}$ & $4(100 \%)$ & ) & ) \\
\hline $\begin{array}{l}\text { Concentration } \\
\text { extracted DNA }\end{array}$ & $0(0 \%)$ & $8(9 \%)$ & $\begin{array}{l}9 \\
(19 \%)\end{array}$ & $1(25 \%)$ & & \\
\hline VAF & $\begin{array}{l}1 \\
(25 \%)\end{array}$ & $\begin{array}{l}26 \\
(30 \%)\end{array}$ & $\begin{array}{l}15 \\
(32 \%)\end{array}$ & NA & & \\
\hline $\begin{array}{l}\text { Disclaimer result } \\
\text { validity }\end{array}$ & $\begin{array}{l}1 \\
(25 \%)\end{array}$ & $1(1 \%)$ & $1(2 \%)$ & $3(75 \%)$ & & \\
\hline $\begin{array}{l}\text { Numbers in green: } e \\
\text { Numbers in red: eler } \\
\text { Numbers in bold: ele } \\
\text { Society of Patholog, }\end{array}$ & $\begin{array}{l}\text { ents th } \\
\text { ts that } \\
\text { ents for } \\
\text { \&T: Gen }\end{array}$ & $\begin{array}{l}\text { vere in } \\
\text { e incly } \\
\text { ch a la } \\
\text { iss (Fr }\end{array}$ & $\begin{array}{l}d \text { by } \\
\text { by } \leq \\
\text { differe }\end{array}$ & $\begin{array}{l}\% \text { of the laborator } \\
\text { of the laboratorie } \\
(\geq 30 \%) \text { exists } b \\
\text { external quality as }\end{array}$ & $\begin{array}{l}\text { hich are required by nation } \\
\text { ich are required by national } \\
\text { en tissue and liquid biopsy } \\
\text { ment scheme) }\end{array}$ & $\begin{array}{l}\text { nternational guidelines } \\
\text { ternational guidelines. } \\
\text { g. ESP: European }\end{array}$ \\
\hline
\end{tabular}

Similarly, eighteen elements are mandatory according to laws/standards valid in Belgium for reporting $(13,15,20)$. Of these, eleven and nine elements were included by all visited laboratories for tissue and liquid biopsy, respectively (marked in green in Table 2B). Elements lacking most often on the report are the reason for testing (for tissue), the DNA extraction method, pre-analytical conditions, an overview of the alterations tested, the reference sequence and the total number of pages (marked in red in Table 2B).

Molecular pathology reports were submitted by 86 laboratories from 24 different countries as part of the molecular subscheme of the ESP Lung EQA scheme of 2019 and 47 laboratories during the Gen\&Tiss scheme. Elements included in these reports from European laboratories are similar to the ones in the visited Belgian laboratories, except for some administrative elements (patient address, the date of sample arrival, the page numbering and the report title), the planned line of therapy, an overview of the alterations tested and the inclusion of the correct reference sequence of the tested genes (Table 2B).

\section{Relation between interpretations and request form}


The relation between the clinical question and the test result interpretation was checked on reports and their corresponding request forms for nine pre-defined situations for tissue testing and six for liquid biopsy testing (Table 3). It should be noted that not all laboratories had requests and reports for all pre-defined situations. For the majority of the testing situations, the clinical question was correctly answered on the report. However, for samples with $A L K$ and $R O S 1$ rearrangements, this was often not the case because of an unclear question on the request form. For instance, in two hospitals the clinician often wrote only 'EGFR?' as a clinical question. It was observed that not for all cases a clear clinical question was present on the request form. 
Table 3

- summary of opinions from pathologists/molecular biologists versus clinicians regarding requesting and reporting in Belgium

Question

\section{Elements on the request form}

Primary diagnosis

Previous tests performed

Original activating mutation

Previous therapies

Tumor stage

Type of progression

Time of progression

Clinical question (reason for testing)

In an ideal world: who is allowed to request additional tests?

Only pathologist

Pathologist and clinician

Only clinician

Other

Current situation: who is allowed to request additional tests?

Only pathologist

Pathologist and clinician

Only clinician

Other (depends on the initial requester)

Which of the following items regarding the request form are important?

The request form is dedicated for molecular testing

The request form is dedicated for specific cancer types

An online version of the request form is available

The indications for testing are indicated on the request form

The testing techniques are indicated on the request form

The tissue/blood recipient is indicated on the request form

The transport medium is indicated on the request form

The max delay for transport is mentioned on the request form

What is the reporting flow in your hospital?

1 integrated report: biomarker results are added when available - WITH a conclusion per biomarker - WITH a conclusion on ALL biomarkers at the end

1 integrated report: biomarker results are added when available - WITH a conclusion per biomarker - WITHOUT a conclusion on ALL biomarkers at the end

\section{Answers from the} laboratory side

\section{Which elements do you often miss? \\ $\mathrm{N}=18$}

2

$3(17 \%)$

$3(17 \%)$

$7(39 \%)$

$9(50 \%)$

$4(22 \%)$

$4(22 \%)$

$3(17 \%)$

$9(50 \%)$

$\mathrm{N}=\mathbf{2 1}$

$2(10 \%)$

$18(86 \%)$

$1(5 \%)$

$0(0 \%)$

$\mathrm{N}=18$

$1(6 \%)$

$9(50 \%)$

$7(39 \%)$

$1(6 \%)$

$\mathrm{N}=0$

-

-

$-$

-

$-$

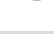

$-$

-

$\mathrm{N}=18$

$6(33 \%)$

$8(44 \%)$
$4(57 \%)$

Answers from pulmonologists

Which elements do you always enter?

$\mathrm{N}=28$

$28(100 \%)$

12 (43\%)

19(68\%)

11 (39\%)

$12(43 \%)$

7 (25\%)

$0(0 \%)$

21 (75\%)

$\mathrm{N}=24$

2 (8\%)

$20(83 \%)$

$2(8 \%)$

$0(0 \%)$

$\mathrm{N}=\mathbf{2 4}$

$4(17 \%)$

$15(63 \%)$

$5(21 \%)$

$0(0 \%)$

$\mathrm{N}=6$

$4(67 \%)$

$5(83 \%)$

0 (0\%)

$6(100 \%)$

$6(100 \%)$

$5(83 \%)$

$4(67 \%)$

$4(67 \%)$

$\mathrm{N}=7$

$3(43 \%)$ 


\begin{tabular}{|c|c|c|}
\hline Question & $\begin{array}{l}\text { Answers from the } \\
\text { laboratory side }\end{array}$ & $\begin{array}{l}\text { Answers from } \\
\text { pulmonologists }\end{array}$ \\
\hline $\begin{array}{l}1 \text { integrated report: biomarker results are added when available - WITHOUT a } \\
\text { conclusion per biomarker - WITH a conclusion on ALL biomarkers at the end }\end{array}$ & $0(0 \%)$ & $0(0 \%)$ \\
\hline Separate reports are released for each biomarker result & $3(17 \%)$ & $0(0 \%)$ \\
\hline Other & $1(6 \%)$ & $0(0 \%)$ \\
\hline How do you receive the report? & $N=0$ & $N=7$ \\
\hline On paper & - & $3(43 \%)$ \\
\hline Via email & - & $1(14 \%)$ \\
\hline Via the hospital information system & - & $6(86 \%)$ \\
\hline Via telephone & - & $0(0 \%)$ \\
\hline Other & - & $0(0 \%)$ \\
\hline Question & $\begin{array}{l}\text { Answers from the } \\
\text { laboratory side }\end{array}$ & $\begin{array}{l}\text { Answers from } \\
\text { pulmonologists }\end{array}$ \\
\hline \multirow[t]{2}{*}{ Elements on the result report } & $\begin{array}{l}\text { What do you think the } \\
\text { clinician needs on the } \\
\text { report? }\end{array}$ & \multirow{2}{*}{$\begin{array}{l}\text { What do you read } \\
\text { on the report? } \\
N=28\end{array}$} \\
\hline & $N=19$ & \\
\hline Clinical interpretation & $14(74 \%)$ & $27(96 \%)$ \\
\hline Description of the analytical method & $1(5 \%)$ & $13(46 \%)$ \\
\hline Sensitivity of the test method & $8(42 \%)$ & $13(46 \%)$ \\
\hline$\%$ neoplastic cells & $4(21 \%)$ & $27(96 \%)$ \\
\hline Genotyping result & $3(16 \%)$ & $18(64 \%)$ \\
\hline Tested regions of the target gene (e.g. which exons) & $3(16 \%)$ & $15(54 \%)$ \\
\hline Variant allelic frequency & $0(0 \%)$ & $1(4 \%)$ \\
\hline $\begin{array}{l}\text { Is it in your hospital appreciated by the clinician to give an interpretation on the } \\
\text { test report? }\end{array}$ & $N=4$ & $N=4$ \\
\hline $\begin{array}{l}\text { Yes, as a general interpretation (e.g. In general, patients with the L858R mutation } \\
\text { in EGFR are sensitive to } 1 \text { st and } 2 \text { nd generation anti-EGFR TKI.) }\end{array}$ & $3(75 \%)$ & $1(25 \%)$ \\
\hline $\begin{array}{l}\text { Yes, as a direct advice (e.g. This patient has a L858R mutation in EGFR and } \\
\text { should be treated with a 1st generation anti-EGFR TKI) }\end{array}$ & $0(0 \%)$ & $2(50 \%)$ \\
\hline Yes, both as a general interpretation or direct advice & $0(0 \%)$ & $1(25 \%)$ \\
\hline No, the clinician wants to make the interpretation & $0(0 \%)$ & $0(0 \%)$ \\
\hline No, but for difficult cases the report is discussed with the clinician & $0(0 \%)$ & $0(0 \%)$ \\
\hline I don't know & $1(25 \%)$ & $0(0 \%)$ \\
\hline Are some biomarker tests outsourced by your hospital? & $N=6$ & $N=3$ \\
\hline Yes & $5(83 \%)$ & $3(100 \%)$ \\
\hline No & $0(0 \%)$ & $0(0 \%)$ \\
\hline I don't know & $1(17 \%)$ & $0(0 \%)$ \\
\hline What is the TAT for biomarker testing for NSCLC in your hospital? & $N=6$ & $N=3$ \\
\hline $1-7$ days & $2(33 \%)$ & $3(100 \%)$ \\
\hline $8-14$ days & $4(67 \%)$ & $0(0 \%)$ \\
\hline
\end{tabular}




\begin{tabular}{|lll|}
\hline Question & $\begin{array}{l}\text { Answers from the } \\
\text { laboratory side }\end{array}$ & $\begin{array}{l}\text { Answers from } \\
\text { pulmonologists }\end{array}$ \\
\hline $15-21$ days & $0(0 \%)$ & $0(0 \%)$ \\
\hline What is the TAT for biomarker testing for NSCLC when tests are outsourced? & $\mathbf{N = 5}$ & $\mathbf{N}=\mathbf{3}$ \\
\hline $1-7$ days & $0(0 \%)$ & $0(0 \%)$ \\
\hline $8-14$ days & $5(100 \%)$ & $3(100 \%)$ \\
\hline $15-21$ days & $0(0 \%)$ & $0(0 \%)$ \\
\hline
\end{tabular}

\section{Content of request forms and reports - opinions from providers and receivers}

During several polling sessions the opinions of both the laboratory side (pathologists and molecular biologists) and the clinician were surveyed. The polling results from both groups are shown in Table 3. Elements that pathologists/molecular biologists were often missing on the request form (despite the fact that clinicians think they include it) were the original actionable variant (if applicable), previous therapies (if applicable) and a clear clinical question. Moreover, clinicians indicated that they wish to see more testing-related information on the request form, such as the indications for testing, the testing techniques and the recipients needed for sampling. For reporting, on the other hand, an item both considered important by both groups is the clinical interpretation of the test result. In addition, clinicians indicated that they also read the percentage of neoplastic cells.

\section{Discussion}

For molecular pathology testing in the field of oncology, continuous and dynamic communication is fundamental between the laboratory and the clinician. When requesting the test in the pre-analytical phase, the laboratory expects the clinician to request the correct test and to provide sufficient information about the patient and the sample that was provided. In the post-analytical phase, it is important to formulate a correct answer to the clinician's question on the basis of the test results.

\section{The total testing process in the visited laboratories}

Because of its different process steps (macroscopic evaluation, microscopic evaluation, DNA extraction, DNA testing, data processing and result interpretation), molecular pathology typically requires a more complex set-up than, for example, classical clinical chemistry. The communication flows differ between the visited laboratories, with anatomical- and molecular pathology being part of one department or being a physically separate department. Potential problems were identified in both contexts. Each time a test is requested, errors can be made by both the clinician (e.g. requesting the wrong test, writing incorrect patient information on the request form) ( 21 , 22), the person registering the request into the laboratory information system (LIS) and by the pathologist requesting molecular testing in case the molecular pathology laboratory is physically separate (either by location or by LIS system). Some copy-paste or transfer errors might be prevented by providing digital request forms via the LIS (23). It could be useful to attach the original pathology report to the request form for molecular testing, since this pathology rapport is likely to contain relevant patient information. Murphy et al. also identified several barriers for reporting the results to the clinicians, including the lack of a reliable process to contact clinicians (23) and to notify clinicians when all results are complete.

Testing strategies differed among visited laboratories. Although reflex testing was previously recommended (24), this is only done by two visited laboratories. Laboratories who used a combination of reflex and parallel testing often do their next-generation sequencing (NGS) testing in parallel with ALK and ROS1 IHC to reduce their turnaround time. In reflex to a positive ROS1 IHC result, a confirmatory FISH test is done, as this is still required according to the latest guidelines from the American Society of Clinical Oncology (25) and the European Society for Medical Oncology (26). Aside from one laboratory, all have tested for EGFR, ALK, ROS1 and PD-L1, which are recommended according to current guidelines for $\operatorname{NSCLC}(25,26)$. These guidelines also concluded that multiplex platforms (NGS) are preferred over applying multiple targeted tests $(25,26)$.

\section{What is currently included vs what should be according to guidelines?}

Although (inter)national guidelines and standards for test requesting and reporting exist, these are often interpretable in different ways and not transferrable to molecular pathology. Although ISO 15189:2012 is an international standard, it was categorized as a standard 'applicable in Belgium' in Tables 2A and 2B since Belgian laboratories have to be accredited for most molecular tests according to a 
national reimbursement law (13). Overall, the analyzed forms and reports comply well with the guidelines applicable in Belgium (Tables $2 \mathrm{~A}$ and $2 \mathrm{~B}$ ). Required elements that were often missing on the request forms include the address and the national reimbursement (RIZIV) number of the prescriber, patient gender and address and the histology of the tumor. The tumor histology is not literally required by IS015189:2012, but can be an interpretation of 'the anatomic site of origin' (16). For reporting, sample arrival dates, page numbering, the DNA extraction method, pre-analytical conditions, overview of the variants tested and reference sequence were included by less than $70 \%$ of the laboratories.

At first sight, the analyzed template request forms for tissue $(\mathrm{N}=4)$ do not closely resemble the template forms for liquid biopsies $(\mathrm{N}=4)$. Major differences between the seven requests analyzed for tissue testing and the five for liquid biopsy testing included: whether the form is dedicated for molecular pathology or not, the name of the test prescriber, the contact person in the laboratory, the primary diagnosis of the patient, the original actionable variant and whether there is progression or not. The latter was included in $80 \%$ of the laboratories, which could be expected since plasma testing for EGFR variants is often done in the context of resistance to 1st and 2nd generation antiEGFR TKIs. Nevertheless, when resistance mutations, such as the p.(Thr790Met) variant, could not be detected (26), the test should be repeated on a tissue sample. Since these resistance mutations can be present at a low variant allelic frequency (27), knowing that the patient progressed might impact the testing strategy and could thus be a clinically relevant item on the request form. Regardless of the differences between tissue and liquid biopsies, there are also items that are missing in both. A first example is the exact reason for testing. It would seem logical that the molecular laboratory can only give a conclusion when a question is asked, but in the majority of cases this is not explicitly formulated. Secondly, the progression type - and time of progression are also often lacking. As mentioned earlier, this is especially relevant for liquid biopsy testing. At the end of the molecular pathology report or during a molecular tumor board meeting, a conclusion has to be made in terms of therapy; which may differ between full-, local- and oligo progression (26).

In addition to the analysis of the request forms, opinions from both the laboratory and requester side were gathered (Table 3 ). Although the number of participants was too low, a discrepancy seems to exist between what pulmonologists claimed they always enter on the request form versus what pathologists often miss, especially for the primary diagnosis, previous test performed, original actionable mutations and clinical question.

It was also analyzed whether sufficient information regarding the testing process was available online. In most laboratories, this was already the case for the sample recipient and transport medium, but not for the test specifications and indications for testing (Table 2A). In addition, the surveys show that the majority of pulmonologists would also like to see the indications, techniques, containers, transport media and transport delay on the application form (Table 3).

For the analyzed reports, the differences between tissue and liquid biopsy testing are less prominent. More abundant in the liquid biopsy reports are the request date, the planned line of therapy, the DNA extraction method, pre-analytical conditions, the reference sequence and a note regarding the result validity. This is to be expected somehow, since the previously mentioned testing context for progression and also because the pre-analytical conditions have more impact on the test result for liquid biopsies (28-30). Of the elements that are present in both report types (page numbering, concise title, planned line of therapy and whether the method is IVD/LDT), only the page numbering is crucial for the report, since loss of a page with critical information of the test can lead to wrong treatment decisions (4).

Overall, the elements described in the reports from the visited Belgian laboratories did not differ substantially from the reports submitted during EQA (Table 2B). However, these four laboratories had all participated in the ESP EQA scheme at least once, which might bias this observation. Nevertheless, several discrepancies existed. The patient's address is less frequently included in EQA. There could be 2 possible explanations; 1 ) this information is in routine often retrieved from the online patient record, which is not available for EQA or 2) this data may have been anonymized for EQA purposes. Elements included at a higher frequency in the French reports are the presence of a title, the page numbering and the sample arrival date. This could be because French laboratories lose points if these elements are missed during the Gen\&Tiss EQA scheme. A similar effect is seen for the overview of alterations tested and the reference sequence for the ESP EQA scheme.

In a similar way as for the request forms, we surveyed laboratory- and pulmonologists' opinions regarding reporting. Both groups agree that the clinical interpretation is a critical element on the report. It might surprise pathologists, but pulmonologists also want to know the percentage of neoplastic cells, although this is a rather technical aspect. It must be noted that the genotyping result is not read by all, which emphasizes that the clinical interpretation must be certainly correct.

Based on these study results, proposed templates for requesting and reporting are shown in Additional file 3 and 4 .

\section{Relation between interpretations and request form}

Page $16 / 22$ 
One of the aims of the study was to determine whether the question asked on the request form was fully answered in the report in 4 Belgium laboratories. Reports were studied for various clinical situations that are representative for NSCLC testing for tissue and liquid biopsies (Table 4) $(26,31)$. It was checked whether a clinical interpretation was given and whether this was written in a 'general' or 'direct' way. By general is meant, for example: "in general, patients with an activating mutation in the EGFR gene show response to $1 \mathrm{st}$ and 2nd generation anti-EGFR TKIs", whereas 'direct' can be rather "this patient will respond to gefitinib". The majority of laboratories gave a general interpretation. No guidelines regarding general interpretations exist, but this is recommended by several external quality assessment providers such as the European Society of Pathology. For ALK-, ROS1- and PD-L1 positive results, the reason for testing was not always reflected. For certain cases the request form only stated "EGFR?". The laboratories claimed that they know the oncologist meant "test all relevant biomarkers for NSCLC", among which ALK, ROS1 and PD-L1. For EGFR plasma testing at initial diagnosis, it was unclear in two laboratories whether progression occurred and therefore both interpretations for first- and second-line therapy were given. Especially in the interpretations for EGFR-positive cases (at initial diagnosis and after progression) different lines of therapy were considered. This makes sense in view of treatment with osimertinib which can be prescribed when the patient has a resistant mutation such as the p.(Thr790Met) variant (26). Note that at the time the study was conducted, osimertinib was not yet approved for first-line treatment. Whether the test result should be discussed in a molecular tumor board is not mentioned on any report. In Belgium, the implementation of molecular tumor boards is still under development. This may be because multidisciplinary oncological consults per cancer type are already mandatory for each patient before therapy can be reimbursed and the need for an additional tumor board, during which only rare gene variants are discussed, therefore seems less important $(13,32)$.

\section{Content of request forms and reports - opinions from providers and receivers}

Apart from a clear content of the request forms and reports, clear "peripheral communication" is important for a smooth process. Given the limited number of molecular pathology laboratories, the group of persons attending the meetings during which their opinions were polled was rather limited. Nevertheless, some trends could be observed. For example, the majority would like both pathologists and clinicians to request tests, which is not always the case now (Table 3). This indicates that there could be a perception that pathologists are more aware of the relevance of certain tests in certain situations. Previous studies in genetics indicated indeed that clinicians do not always feel confident about their choice of test $(33,34)$. In most laboratories clinicians receive the report via the hospital information system. A possible hazard is that in the majority of cases reports are built in this system as integrated reports, but without a single conclusion at the end. It is then the responsibility of the clinician to make a therapy decision based on all single test results, which can be challenging. Based on literature, reporting in a timely manner was found to be burdensome (35), but the survey results indicated that pulmonologists rather under- than overestimate the turnaround time (Table 3).

\section{Conclusions}

In conclusion, this study identified different communication flows between the laboratory (both anatomical- and molecular pathology) and the clinician, different content in request forms and result reports and different opinions from both pathologists and clinicians in Belgium. Although the number of visited laboratories and polled pathologists and clinicians was rather limited, several trends were clear which add to the need for standardization of the test requesting and reporting process in Belgium. Existing guidelines and standards on the content of test request forms and result reports are vague, yet not all elements were included in the visited laboratories. The interpretation is the most important element of the report and should contain an answer to the question asked in the request. Based on the study results in Belgium, a template for complete requesting and reporting was proposed, which could harmonize communication flows. The reports analyzed during EQA showed similar results. Nevertheless, it should be further studied to which extent EQA reports resemble routine reports. In addition, automatization of the flow might reduce typing/copy-pasting errors. Therefore, the authors also wish to communicate these observations to programmers/vendors of electronic forms/reporting system so the necessary elements can be implemented.

\section{Abbreviations}

ALK Anaplastic lymphatic kinase

BRAF B-Raf murine sarcoma viral oncogene homolog B

ddPCR Digital droplet polymerase chain reaction

Page $17 / 22$ 
DOB Date of birth

EGFR Epidermal growth factor receptor

EQA External quality assessment

ESP European Society of Pathology

FISH Fluorescence in situ hybridisation

G\&T Gen\&Tiss

H\&E Hematoxylin and eosin

IHC Immunohistochemistry

ISO International organisation for standardisation

IVD In vitro diagnostic

KRAS Kirsten rat sarcoma viral oncogene homolog

LB Liquid Biopsy

LDT Laboratory developed test

LIS Laboratory information system

MET Mesenchymal to Epithelial Transition

NCP Neoplastic cell percentage

NGS Next generation sequencing

NSCLC Non-small-cell lung cancer

PCR Polymerase chain reaction

PDL1 Programmed deadth ligand 1

QC Quality control

RECIST Response evaluation criteria in solid tumors

ROS1 ROS Proto-Oncogene 1

TKI Tyrosin kinase inhibitor

TNM Tumor, Nodes and Metastases

VAF Variant allelic frequency

WT Wild type

\section{Declarations}

\section{Ethics approval and consent to participate}

Not applicable since it concerned a retrospective observational study on anonymized data. The requirement for ethical approval for the present study was waived by The Research Ethics Committee of KU/UZ Leuven and an official waiver was obtained since the study is of retrospective and observational nature with patient data. No informed consent was necessary for this study since no patients or 
identifying personal data will be used or accessed.

For the analysis of the request forms and reports, written permission was obtained from the visited hospitals to access anonymized data. The data (request forms and result reports) were anonymized and printed from the laboratory information system by a representative from the visited laboratory. Access to the original dataset in the laboratory information system was not permitted to assure the privacy of the patients.

For a second study part, we developed a survey for collecting general information (opinions and questions regarding their requesting and reporting procedures) from the clinicians and molecular pathologists. Informed consent was obtained from all the participants for the study. Only aggregate data were collected, which were anonymized prior to use. All participants consented to the use of these aggregate data.

\section{Consent for publication}

Not applicable

\section{Availability of data and materials}

The datasets used and/or analyzed during the current study are available from the corresponding author on reasonable request.

\section{Competing interests}

ES received honoraria for consultancy/advisory board from AstraZeneca, Roche, Pfizer, Bayer, Novartis, BMS, MSD/Merck, BioRad, Illumina, Ageno BioSciences, Janssen Cilag (Johnson\&Johnson), BioCartis; speaker's fee AstraZeneca, Roche, Pfizer, Novartis, BioRad, Illumina, Ageno BioSciences, BioCartis; (unrestricted) grants from Boehringer Ingelheim, BMS, Biocartis, BioRad, Ageno BioSciences and Roche (All outside the submitted work and fees to UMCG). JvdT is a member of the advisory boards of BMS, MSD and Roche. EDQ received a research grant from AstraZeneca.

$\mathrm{KD}, \mathrm{KVC}, \mathrm{JB}, \mathrm{NDH}, \mathrm{CVC}, \mathrm{SVB}, \mathrm{ER}$ and $\mathrm{KZ}$ have nothing to declare.

\section{Funding}

For this research funding was provided by AstraZeneca Belgium Nv. In terms of content, all steps of the research (conceptualization, data collection, data analysis, interpretation and writing of the manuscript) were carried out independently of the funder.

\section{Author's contributions}

KD was involved in the Conceptualization, Methodology, Validation, Formal analysis, Investigation, Writing and Visualization. KVC was involved in Methodology, Validation, Formal analysis, Investigation and Writing (Review and editing). JB, NDH, CVC, SVB, KZ, ER, ES and JvdT were involved in Validation, Investigation and Writing (Review and editing). EDQ was responsible for Conceptualization, Investigation, Writing (Review and Editing) and Supervision.

\section{Acknowledgements}

The authors wish to thank the laboratories which participated in the laboratory visits, the ESP Lung EQA scheme of 2019 and the Gen\&Tiss scheme of 2018-2019. In addition, dr. Cleo Keppens, dr. Inne Nauwelaers, prof. dr. Patrick Pauwels, prof. dr. Ales Ryska, prof. dr. Izidor Kern, dr. Federica Pezzuto, dr. Alexandre Harlé, dr. Aude Lamy and dr. Ludovic Lacroix are thanked for their expertise as an assessor of the EQA schemes and dr. Raed Al Dieri as the general direct of the ESP. We are grateful for the financial support provided by AstraZeneca Belgium Nv.

\section{References}

1. Scheuner MT, Edelen MO, Hilborne LH, Lubin IM, Board RMGTRA. Effective communication of molecular genetic test results to primary care providers. Genet Med. 2013;15(6).

2. Romano RC, Novotny PJ, Sloan JA, Comfere NI. Measures of Completeness and Accuracy of Clinical Information in Skin Biopsy Requisition Forms: An Analysis of 249 Cases. Am J Clin Pathol. 2016;146(6).

3. LaDuca H, McFarland R, Gutierrez S, Yussuf A, Ho N, Pepper J, et al. Quality of Clinician-Reported Cancer History When Ordering Genetic Testing. JCO Clin Cancer Inform. 2018;2. 
4. Tack V, Dufraing K, Deans ZC, van Krieken HJ, Dequeker EMC. The ins and outs of molecular pathology reporting. Virchows Arch. 2017;471(2).

5. Simpson RW, Berman MA, Foulis PR, Divaris DX, Birdsong GG, Mirza J, et al. Cancer biomarkers: the role of structured data reporting. Arch Pathol Lab Med. 2015;139(5).

6. Heller DS. Areas of Confusion in Pathologist-Clinician Communication as it Relates to Understanding the Vulvar Pathology Report. J Low Genit Tract Dis. 2017;21(4).

7. Lubin IM, McGovern MM, Gibson Z, Gross SJ, Lyon E, Pagon RA, et al. Clinician perspectives about molecular genetic testing for heritable conditions and development of a clinician-friendly laboratory report. J Mol Diagn. 2009;11(2).

8. Soria JC, Ohe Y, Vansteenkiste J, Reungwetwattana T, Chewaskulyong B, Lee KH, et al. Osimertinib in Untreated EGFR-Mutated Advanced Non-Small-Cell Lung Cancer. N Engl J Med. 2018;378(2).

9. Alix-Panabières C, Pantel K. Real-time liquid biopsy: circulating tumor cells versus circulating tumor DNA. Ann Transl Med. 2013;1(2).

10. C D. Therapy-orienting testing of EGFR inhibitor-resistant non-small cell lung cancer. Belg J Med Oncol. 2017;11(5).

11. van Krieken JH, Normanno N, Blackhall F, Boone E, Botti G, Carneiro F, et al. Guideline on the requirements of external quality assessment programs in molecular pathology. Virchows Arch. 2013;462(1).

12. Kadivar M, Rahimabad PK. Missing Elements in Surgical Pathology Reports: Breast, Colon and Stomach Cancers. Asian Pac J Cancer Prev. 2016;17(3).

13. Belgian Law of 10 November 2012 - Royal Decree amending the Article 33 of the Annex to the Royal Decree of 14 September 1984 establishing the nomenclature of medical benefits in respect of compulsory insurance for medical care and benefits.

14. Mise à jour 2011 des comptes rendus d'anatomopathologie: données minimales à renseigner pour une tumeur primitive, Traitements, soins et innovations, INCa, Boulogne-Billancourt, décembre 2011.

15. Belgian Law of 5 December 2011 - Royal Decree concerning the recognition of the laboratories for pathological anatomy by the Minister to whose authority Public Health belongs.

16. International Organization for Standardization: ISO 15189:2012 Medical laboratories - Particular requirements for quality and competence. 2012 ISO Geneva, Switzerland.

17. Cagle PT, Sholl LM, Lindeman NI, Alsabeh R, Divaris DX, Foulis $\mathrm{P}$, et al. Template for reporting results of biomarker testing of specimens from patients with non-small cell carcinoma of the lung. Arch Pathol Lab Med. 2014;138(2).

18. Keppens C, Tack V, Hart N, Tembuyser L, Ryska A, Pauwels P, et al. A stitch in time saves nine: external quality assessment rounds demonstrate improved quality of biomarker analysis in lung cancer. Oncotarget. 2018;9(29).

19. Dequeker EM, Keppens C, Egele C, Delen S, Lamy A, Lemoine A, et al. Three Rounds of External Quality Assessment in France to Evaluate the Performance of 28 Platforms for Multiparametric Molecular Testing in Metastatic Colorectal and Non-Small Cell Lung Cancer. J Mol Diagn. 2016;18(2).

20. Code of practice for setting up a quality system in approved laboratories for pathological anatomy operating within the framework of the Royal Decree of 5 December 2011. Available via https://www.wiv-isp.be/QML/commissionanapath/document_nl/Praktijkrichtlijn-PA.pdf (last accessed: 16/01/2021).

21. McDonnell M, Group NIRA. An audit of tumour marker requests in Northern Ireland. Ann Clin Biochem. 2004;41(Pt 5).

22. Azim HA, Michiels S, Zagouri F, Delaloge S, Filipits M, Namer M, et al. Utility of prognostic genomic tests in breast cancer practice: The IMPAKT 2012 Working Group Consensus Statement. Ann Oncol. 2013;24(3).

23. Murphy DR, Satterly T, Rogith D, Sittig DF, Singh H. Barriers and facilitators impacting reliability of the electronic health recordfacilitated total testing process. Int J Med Inform. 2019;127.

24. Kerr KM, Bubendorf L, Edelman MJ, Marchetti A, Mok T, Novello S, et al. Second ESMO consensus conference on lung cancer: pathology and molecular biomarkers for non-small-cell lung cancer. Ann Oncol. 2014;25(9).

25. Lindeman NI, Cagle PT, Aisner DL, Arcila ME, Beasley MB, Bernicker EH, et al. Updated Molecular Testing Guideline for the Selection of Lung Cancer Patients for Treatment With Targeted Tyrosine Kinase Inhibitors: Guideline From the College of American Pathologists, the International Association for the Study of Lung Cancer, and the Association for Molecular Pathology. J Mol Diagn. 2018;20(2).

26. Planchard D, Popat S, Kerr K, Novello S, Smit EF, Faivre-Finn C, et al. Metastatic non-small cell lung cancer: ESMO Clinical Practice Guidelines for diagnosis, treatment and follow-up. Ann Oncol. 2019;30(5). 
27. O'Kane GM, Liu G, Stockley TL, Shabir M, Zhang T, Law JH, et al. The presence and variant allele fraction of EGFR mutations in ctDNA and development of resistance. Lung Cancer. 2019;131.

28. Sorber L, Zwaenepoel K, De Winne K, Van Casteren K, Augustus E, Jacobs J, et al. A Multicenter Study to Assess. Cancers (Basel). 2018;10(9).

29. Garcia J, Dusserre E, Cheynet V, Bringuier PP, Brengle-Pesce K, Wozny AS, et al. Evaluation of pre-analytical conditions and comparison of the performance of several digital PCR assays for the detection of major. Oncotarget. 2017;8(50).

30. de Kock R, Deiman B, Kraaijvanger R, Scharnhorst V. Optimized (Pre) Analytical Conditions and Workflow for Droplet Digital PCR Analysis of Cell-Free DNA from Patients with Suspected Lung Carcinoma. J Mol Diagn. 2019;21(5).

31. Esposito Abate R, Pasquale R, Fenizia F, Rachiglio AM, Roma C, Bergantino F, et al. The role of circulating free DNA in the management of NSCLC. Expert Rev Anticancer Ther. 2019;19(1.

32. Koopman B, Wekken AJvd, Elst At, Hiltermann TJN, Vilacha JF, Groves MR, et al. Relevance and Effectiveness of Molecular Tumor Board Recommendations for Patients With Non-Small-Cell Lung Cancer With Rare or Complex Mutational Profiles. JCO Precision Oncology. 2020(4).

33. Gingras I, Sonnenblick A, de Azambuja E, Paesmans M, Delaloge S, Aftimos P, et al. The current use and attitudes towards tumor genome sequencing in breast cancer. Sci Rep. 2016;6.

34. Gray SW, Hicks-Courant K, Cronin A, Rollins BJ, Weeks JC. Physicians' attitudes about multiplex tumor genomic testing. J Clin Oncol. 2014;32(13).

35. Lankshear S, Srigley J, McGowan T, Yurcan M, Sawka C. Standardized synoptic cancer pathology reports - so what and who cares? A population-based satisfaction survey of 970 pathologists, surgeons, and oncologists. Arch Pathol Lab Med. 2013;137(11).

36. The Royal College of Pathologists of Australasia. Lung Cancer Histopathology Request Information. Available online via https://www.rcpa.edu.au/getattachment/7dac3f4e-df20-4f7b-800f-5b562377d648/Request-lung-cancer.aspx (last accessed: 16/01/2021).

37. The Royal College of Pathologists of Australasia. Lung Cancer Histopathology Reporting Proforma. Available online via https://www.rcpa.edu.au/getattachment/bdbd0b0f-0b35-417d-ba98-1f0051d5ac96/Proforma-lung-cancer.aspx (last accessed: 16/01/2021).

\section{Figures}
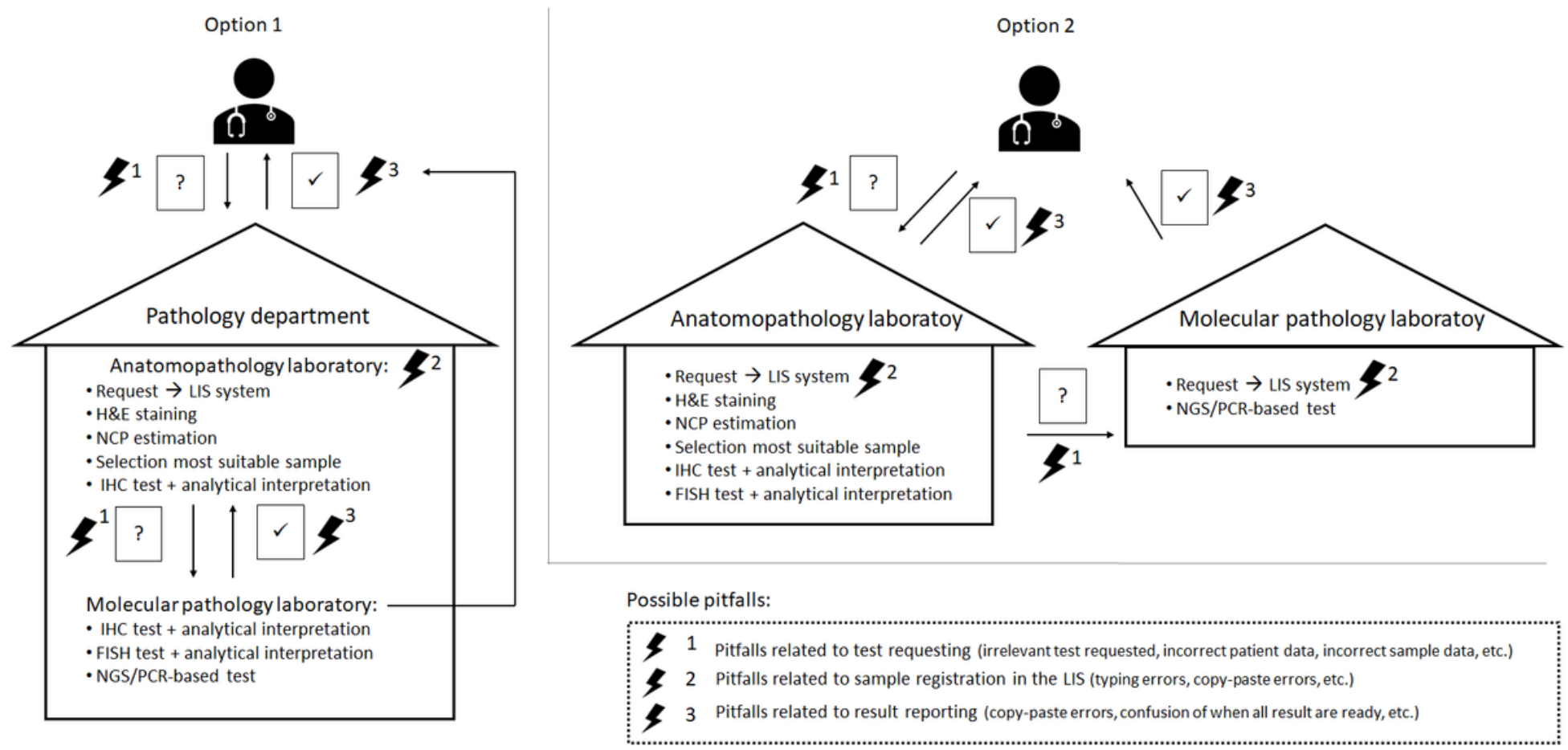

Figure 1 
Communication flows and their pitfalls between pathologists/molecular biologists and clinician in Belgium Option 1: the anatomic pathology- and molecular pathology laboratory are part of the same unit and located at the same place. Option 2: the anatomic pathology- and molecular pathology laboratory are distinct units and might have separate locations, LIS: laboratory information system, H\&E: hematoxylin and eosin, NCP: neoplastic cell percentage, IHC: immunohistochemistry, FISH: fluorescent in-situ hybridization, NGS: next-generation sequencing, PCR: polymerase chain reaction.

\section{Supplementary Files}

This is a list of supplementary files associated with this preprint. Click to download.

- Additionalfile1.docx

- Additionalfile2.docx

- Additionalfile3.docx

- Additionalfile4.docx 